\title{
PENGARUH PENERAPAN INKLUSI KEUANGAN TERHADAP PERTUMBUHAN EKONOMI DI INDONESIA
}

\author{
Firdha Aksari Anindyntha a* \\ ${ }^{a}$ Ekonomi Pembangunan, Fakutas Ekonomi dan Bisnis, Universitas \\ Muhammadiyah Malang, Indonesia \\ * Corresponding author: firdhaaksari@umm.ac.id
}

\begin{tabular}{|c|c|}
\hline Artikel Info & Abstract \\
\hline $\begin{array}{l}\text { Article history: } \\
\text { Received 16 Desember } 2019 \\
\text { Revised } 26 \text { December } 2019 \\
\text { Accepted } 10 \text { January } 2020 \\
\text { Available online } 15 \text { February } \\
2020\end{array}$ & $\begin{array}{l}\text { The creation of financial system stability through the } \\
\text { application of financial inclusion is a national } \\
\text { development strategy to encourage economic growth. } \\
\text { Financial inclusion consists of three indices, namely } \\
\text { availability, access, and usage. The purpose of this } \\
\text { research is to determine the effect of the application of } \\
\text { financial inclusion on economic growth in Indonesia. The }\end{array}$ \\
\hline $\begin{array}{l}\text { Keyword: financial inclusion, } \\
\text { availability, access, usage, } \\
\text { economic growth }\end{array}$ & $\begin{array}{l}\text { method in this study uses Partial Least Square (PLS) } \\
\text { analysis because the independent variable (financial } \\
\text { inclusion index) is a latent variable that has many } \\
\text { indicators. The results of the analysis show that of the } \\
\text { three financial inclusion indices, there are two indices } \\
\text { that influence economic growth, namely availability with } \\
\text { indicators of ATM machine availability and access with } \\
\text { indicators of account ownership, debit cards, and e- } \\
\text { money cards. }\end{array}$ \\
\hline
\end{tabular}

\section{PENDAHULUAN}

Pertumbuhan ekonomi merupakan indikator yang dapat mencerminkan kondisi perekonomian suatu negara. Negara akan selalu berusaha untuk meningkatkan pertumbuhan ekonominya dari waktu ke waktu sebagai upaya untuk mencapai pembangunan ekonomi. Umumnya ukuran pertumbuhan ekonomi dilihat dari Produk Domestik Bruto (PDB). Terdapat banyak sektor yang dapat mempengaruhi pertumbuhan ekonomi, salah satunya adalah melalui sektor keuangan. Cheng \& Degryse (2010) menyebutkan bahwa pembangunan sektor keuangan, khususnya perbankan dapat meningkatkan akses dan penggunaan jasa perbankan oleh masyarakat sehingga dapat mendorong pertumbuhan ekonomi. Salah satu bukti dari pembangunan ekonomi yang berkualitas adalah terciptanya stabilitas sistem keuangan melalui penerapan inklusi keuangan sehingga dapat memberi manfaat bagi seluruh lapisan masyarakat.

Istilah keuangan inklusif mulai marak diperkenalkan pasca krisis tahun 2008 yang didasari oleh dampak krisis terhadap kelompok in the bottom of pyramid, yaitu orang yang berpendapatan rendah, tinggal di daearah terpencil, orang cacat, buruh yang tidak memiliki dokumen indentitas legal, dan masyarakat pinggiran dimana tidak tersentuh oleh sektor perbankan (unbanked) tercacat sangat tinggi di luar negara maju (Bank Indonesia, 2020). (Bank Indonesia, 2014) menyebutkan bahwa inklusi keuangan merupakan strategi pembangunan nasional untuk mendorong pertumbuhan ekonomi melalui pemerataan pendapatan, pengentasan kemiskinan serta stabilitas sistem keuangan. Definisi inklusi keuangan mengacu pada akses universal ke 
berbagai layanan keuangan dengan biaya yang rasional (Ouma et al., 2017); (Swamy, 2014); (Zins \& Weill, 2016). Penerapan inklusi keuangan pada suatau negara diukur melalui Indeks Inklusi Keuangan (IIK). Perhitungan IIK yang dikembangankan oleh (Sarma, 2008) dan (Hanivan \& Nasrudin, 2019) terdiri dari Access, Availability, serta Usage. Secara umum, inklusi keuangan memiliki dampak pada pertumbuhan ekonomi jangka panjang dan upaya untuk pengentasan kemisminan (Uddin et al., 2014). Pertumbuhan ekonomi Indonesia sebagai negara berkembang menunjukkan angka yang cukup baik. Namun dalam tiga tahun terakhir cenderung berfluktuasi. Data dari Badan Pusat Statistik (2019) menunjukkan bahwa pada tahun 2017 pertumbuhan ekonomi sebesar $5,19 \%$ dan dalam dua tahun berikutnya justru mengalami perlambatan, dimana tahun 2018 menurun $0,01 \%$ menjadi 5,18\%. Sedangkan di akhir tahun 2019 pertumbuhan ekonomi turun menjadi 4,97\%. Perlambatan ekonomi Indonesia dipengaruhi banyak faktor baik dari internal dalam negeri maupun dari goncangan ekonomi internasional. Pertumbuhan ekonomi Indonesia yang secara kuantitas relatif tinggi diiringi pula dengan pesatnya perkembangan industri keuangan. Sayangnya perkembangan industri keuangan tidak disertai dengan akses layanan jasa keuangan terhadap seluruh masyarakat di Indonesia. Berdasarkan laporan yang dirilis World Bank dalam Global Findex (Financial Inclusion Index) tahun 2017, jumlah masyarakat Indonesia dewasa yang memiliki rekening di institusi keuangan hanya sebesar 48\% dan sisanya 52\% atau 60 juta masyarakat Indonesia belum memiliki rekening. Terapat beberapa alasan yang membuat orang Indonesia tidak memiliki rekening di institusi keuangan. Terdapat $72 \%$ orang yang tidak memiliki rekening karena tidak memiliki cukup dana untuk menabung, dimana masyarakat ini tergolong miskin atau memiliki pendapatan rendah sehingga hanya cukup digunakan untuk konsumsi. Selanjutnya adalah alasan jarak dengan institusi keuangan sebesar 33\%, dan hanya sangat kecil persentase yang menyatakan alasan kurangnya motivasi atau tidak butuh rekening yaitu sebesar 1,69\% dari total masyarakat dewasa.

Sarma \& Pais (2008) menyebutkan bahwa inklusi keuangan mengacu pada proses yang menjamin kemudahan akses, ketersediaan dan penggunaan sistem keuangan formal untuk semua anggota ekonomi. Peningkatan financial inclusion akan diikuti oleh penguatan basis tabungan yang dapat digunakan untuk meningkatkan proses intermediasi (Khan, 2011). Melalui peningkatan akses keuangan dapat memperluas pilihan masyarakat untuk memanfaatkan kesempatan ekonomi yang pada akhirnya akan meningkatkan produktifitas dan efieiensinya sebagai pelaku ekonomi sehingga dapat meningkatkan pertumbuhan ekonomi. Pada beberapa studi disebutkan bahwa terdapat pengaruh positif inklusi keuangan terhadap pertumbuhan ekonomi suatu negara yang artinya peningkatan inklusi keuangan dapat meningkatkan pertumbuhan ekonomi. Kim et al. (2018) menyimpulkan bahwa inklusi keuangan secara signifikan berpengaruh positif terhadap pertumbuhan ekonomi di negara-negara anggota Organization of Islamic Cooperation meskipun terdapat pebedaan tingkat inklusi keuangan di masing-masing negara. Hasil penelitian lain dengan alat anaisis beragam dan studi kasus pada negara yang berbeda-beda menunjukkan bahwa inklusi 
keuangan memiliki pengaruh positif terhadap pertumbuhan ekonomi (Onaolapo, 2015); (Sharma, 2016); (Anwar \& Amri, 2017); (Sethi \& Acharya, 2018); (Mwaitete \& George, 2018).

Beberapa penelitian tentang inklusi keuanagan sebelumnya dari (Sarma, 2008); (Ummah et al., 2018); (Cámara \& Tuesta, 2017); (Sanjaya, I Made, 2016); (Hanivan \& Nasrudin, 2019) mencoba untuk membangun atau menghitung indeks yang digunakan untuk mengukur inklusi keuangan pada suatu wilayah atau negara. Penelitian lain dari Hannig \& Jansen (2011); Dupas et al. (2012); dan Dienillah \& Anggraeni (2016) adalah melihat pengaruh inklusi keuangan terhadap stabilitas sistem keuangan yang dapat berdampak pada stabilitas ekonomi, pertumbuhan ekonomi, kemiskinan, dan ketimpangan. Analisis yang digunakan untuk melihat pengaruh inklusi keuangan pada penelitian sebelumnya sebagian besar menggunakan regresi dan penggunaan variabel independen inklusi keuangan hanya memakai sebagian dari komponen dalam indeks inklusi keuangan.

Perbedaan penelitian ini dengan sebelumnya adalah mencoba untuk menggunakan semua komponen dalam indeks inklusi keuangan yang telah ditetapkan dari penelitian sebelumnya maupun otoritas moneter Bank Indonesia untuk melihat bagaimana pengaruhnya terhadap pertumbuhan ekonomi tanpa menghitung nilai dari indeks inklusi keuangan. Alat analisis yang digunakan pun bukan regresi tetapi PLS karena tiga indeks inklusi keuangan memiliki komponen yang cukup banyak. Dengan demikian, tujuan dari penelitian adalah untuk mengetahui dan menganalisis pengaruh penerapan inklusi keuangan terhadap pertumbuhan ekonomi di Indonesia. Harapan kedepan adalah pemerintah melibatkan peran inklusi keuangan dalam menentukan alternatif kebijakan untuk mendorong peningkatan pertumbuhan ekonomi di Indonesia.

\section{METODE PENELITIAN}

Jenis penelitian ini adalah kuantitatif untuk mengetahui pengaruh inklusi keuangan terhadap pertumbuhan ekonomi di Indonesia. Sumber data adalah sekuder, dimana data pertumbuhan ekonomi diperoleh dari Badan Pusat Statistik dan data indeks inklusi keuangan dari Bank Indonesia. Periode waktu penelitian adalah tahun 2012 - 2019 dengan data triwulan. Variabel depedenden dalam penelitian adalah pertumbuhan ekonomi yang diukur melalui Produk Domestik Bruto (PDB), sedangkan variabel independen menggunakan indeks inklusi keuangan dari Bank Indonesia, yaitu Access, Availability, dan Usage. Komponen dalam indeks inklusi keuangan mengikuti penelitian dari (Sarma \& Pais, 2008); (Hanivan \& Nasrudin, 2019) serta indikator keuangan inklusi dari Bank Indonesia.

Tabel 1. Komponen Indeks Inklusi Keuangan

\begin{tabular}{ll}
\hline Availability & Jumlah kantor layanan bank \\
Jumlah mesin ATM
\end{tabular}




\begin{tabular}{ll}
\hline & Kartu Debit \\
Access & Kartu Kredit \\
& Jumlah Rekening \\
& Kartu e-money \\
\hline & Volume transaksi debit \\
Usage & Volume transaksi kredit \\
& DPK perbankan terhadap GDP \\
& Kredit perbankan terhadap GDP \\
\hline
\end{tabular}

Pada tabel 1 telah disebutkan komponen dalam indeks inklusi keuangan yang akan digunakan sebagai variabel independen. Indeks inklusi keuangan yang pertama adalah Availability yang menunjukkan ketersediaan layanan perbankan untuk masyarakat, meliputi jumlah kantor layanan bank dan jumlah mesin ATM. Jumlah kantor layanan bank merupakan total kesluruhan kantor bank yang menyediakan layanan untuk masyarakat di Indonesia dengan satuan unit. Sedangkan jumlah mesin ATM adalah total ketersediaan mesin ATM di selutuh wilayah Indonesia dengan satuan unit.

Indeks inklusi keuangan yang kedua adalah Access dimana menunjukkan akses masyarakat terhadap layanan keuangan terdiri dari jumlah rekening, kartu debit, kartu kredit, dan kartu e-money. Jumlah rekening menunjukkan jumlah kepemilikan rekening orang dewasa di perbankan seluruh Indonesia. Kartu debit merupakan jumlah kepemilikan kartu debit orang dewasa di Indonesia dengan satuan unit. Sedangkan untuk kartu kredit adalah jumlah kepemilikan kartu kredit orang dewasa di Indonesia dengan satuan unit. Kartu e-money menunjukkan jumlah kepemilikan kartu uang elektronik orang dewasa di Indonesia dengan satuan unit.

Indeks inklusi keuangan yang terakhir, yaitu Usage yang menunjukkan penggunaan produk perbankan oleh masyarakat terdiri dari volume transaksi debit, volume transaksi kredit, DPK perbankan terhadap GDP, dan kredit perbankan terhadap GDP. Volume transaksi debit adalah volume transaksi yang dilakukan dengan menggunakan kartu debit. Sedangkan untuk volume transaksi kredit merupakan volume transaksi yang dilakukan dengan menggunakan kartu kredit. DPK perbankan terhadap GDP merupakan rasio perbandingan antara total DPK terhadap total GDP dalam bentuk persentase. Kredit perbankan terhadap GDP adalah rasio perbandingan antara total kredit terhadap GDP dalam bentuk persentase.

Alat analisis yang digunakan adalah Partial Least Square (PLS) untuk mengetahui pengaruh penerapan inklusi keuangan terhadap pertumbuhan ekonomi di Indonesia. Analisis PLS dipilih mengingat setiap variabel independen (indeks inklusi keuangan) adalah variabel laten yang memiliki banyak komponen. Tidak semua komponen sesuai menunjukkan pengaruh terhadap variabel dependen, sehingga komponen-komponen dari variabel independen harus dipilih yang sesuai menggambarkan varaibel independen dan memiliki pengaruh terhadap variabel dependen pertumbuhan ekonomi. Model PLS dalam penelitian ini adalah sebagai berikut: 
Gambar 1. Model Penerapan Inklusi Keuangan Terhadap Pertumbuhan Ekonomi

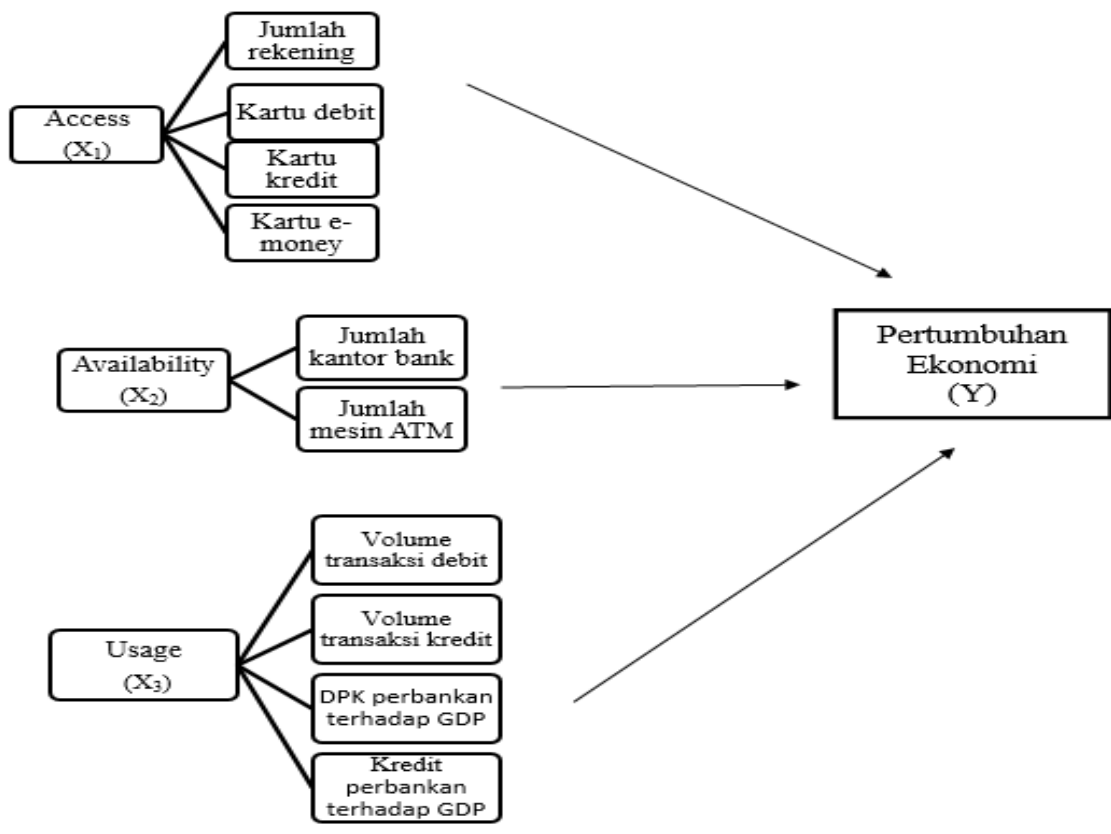

Analisis data dengan Partial Least Square (PLS) terdapat dua evaluasi model yang dilakukan. Pertama adalah evaluasi model pengukuran (outer model) yang terdiri dari uji validitas dan reliabilitas. Selanjutnya adalah evaluasi model struktural (inner model) meliputi pengujian R2, predictive relevance (Q2), path coefficient (koefisien jalur) dan uji signifikansi, serta model fit.

\section{HASIL DAN PEMBAHASAN}

Tujuan dari penelitian ini adalah untuk mengetahui dan menganalisis pengaruh penerapan inklusi keuangan terhadap pertumbuhan ekonomi di Indonesia dengan menggunakan Partial Least Square (PLS). Evaluasi model yang pertama adalah evaluasi model pengukuran (outer model) terdiri dari uji validitas dan uji reliabilitas. Uji validitas adalah pengujian validitas untuk indikator reflektif yang dilakukan dengan menggunakan korelasi antara nilai variabel indikator dengan nilai variabel konstruknya. Hasil uji ini dapat diketahui dari perhitungan program smart PLS pada outer loading.

\section{Tabel 2. Hasil Outer Loading 1}

\begin{tabular}{lcccc}
\hline & Availability & Access & Usage & Pertumbuhan Ekonomi \\
\hline & $\mathrm{X} 1$ & $\mathrm{X} 2$ & $\mathrm{X} 3$ & $\mathrm{Y}$ \\
X1.1 & $\mathbf{0 , 5 4 0}$ & & & \\
$\mathrm{X} 1.2$ & 0,926 & & & \\
X2.1 & & 0,862 & & \\
X2.2 & & $\mathbf{0 , 4 1 6}$ & & \\
\hline
\end{tabular}




\begin{tabular}{|c|c|c|c|c|}
\hline & Availability & Access & Usage & Pertumbuhan Ekonom \\
\hline $\mathrm{X} 2.3$ & & 0,901 & & \\
\hline $\mathrm{X} 2.4$ & & 0,837 & & \\
\hline X3.1 & & & 0,874 & \\
\hline $\mathrm{X} 3.2$ & & & 0,508 & \\
\hline X3.3 & & & 0,053 & \\
\hline X3.4 & & & 0,286 & \\
\hline $\mathrm{Y}$ & & & & 1,000 \\
\hline
\end{tabular}

Pada tabel 2 terlihat bahwa terdapat indikator yang tidak valid karena memiliki nilai < 0,7 yaitu indikator X1.1 (jumlah kantor bank), X2.2 (kartu kredit), X3.2 (volume transaksi kredit), X3.3 (DPK terhadap GDP), dan X3.4 (krdit terhadap GDP), sehingga lima indikator tersebut dikeluarkan dari model supaya memperoleh model struktural yang sesuai untuk penelitian. Setelah lima indikator dikeluarkan maka diperoleh hasil dari uji validitas konvergen bahwa semua indikatornya telah valid karena memiliki nilai $>0,7$ yang ditampilkan pada tabel 3.

Tabel 3. Hasil Outer Loading 2

\begin{tabular}{|c|c|c|c|c|}
\hline & Availability & Access & Usage & Pertumbuhan Ekonomi \\
\hline & $\mathrm{X} 1$ & $\mathrm{X} 2$ & X3 & $\mathrm{Y}$ \\
\hline $\mathrm{X} 1.2$ & 0,926 & & & \\
\hline $\mathrm{X} 2.1$ & & 0,862 & & \\
\hline $\mathrm{X} 2.3$ & & 0,901 & & \\
\hline $\mathrm{X} 2.4$ & & 0,837 & & \\
\hline X3.1 & & & 0,874 & \\
\hline $\mathrm{Y}$ & & & & 1,000 \\
\hline
\end{tabular}

Selanjutnya adalah uji validitas diskriminan dimana diperlukan pada indikator reflektif dengan membandingkan nilai pada tabel hasil cross loading. Suatu indikator dinyatakan valid jika mempunyai nilai loading factor tertinggi pada variael konstruk yang dituju ketika dibandingkan dengan nilai loading factor terhadap variabel konstruk lainnya.

Tabel 4. Hasil Cross Loading 2

\begin{tabular}{ccccc}
\hline & Availability & Access & Usage & Pertumbuhan Ekonomi \\
\hline & $\mathrm{X} 1$ & $\mathrm{X} 2$ & $\mathrm{X} 3$ & $\mathrm{Y}$ \\
$\mathrm{X} 1.2$ & $\mathbf{1 , 0 0 0}$ & 0,760 & 0,613 & 0,897 \\
$\mathrm{X} 2.1$ & 0,663 & $\mathbf{0 , 8 7 3}$ & 0,359 & 0,759 \\
$\mathrm{X} 2.3$ & 0,803 & $\mathbf{0 , 9 1 8}$ & 0,424 & 0,884 \\
X2.4 & 0,521 & $\mathbf{0 , 8 5 1}$ & 0,453 & 0,727 \\
X3.1 & 0,613 & 0,467 & $\mathbf{1 , 0 0 0}$ & 0,524 \\
$\mathrm{Y}$ & 0,897 & 0,901 & 0,524 & $\mathbf{1 , 0 0 0}$ \\
\hline
\end{tabular}

Sumber : data diolah, 2020 
Tabel 4 menunjukkan bahwa nilai loading factor setiap indikator terhadap konstruknya lebih besar dibandingkan nilai loading factor terhadap konstruk lain. Berdasarkan hasil uji validitas konvergen dan diskriminan menunjukkan bahwa semua indikator dari variabel endogen maupun eksogen telah valid. Dengan demikian terdapat modifikasi model dalam penelitian dari analisa PLS sebagaimana ditampilkan pada gambar 2.

\section{Gambar 2. Konstruksi Diagram Jalur PLS Setelah Modifikasi Model}

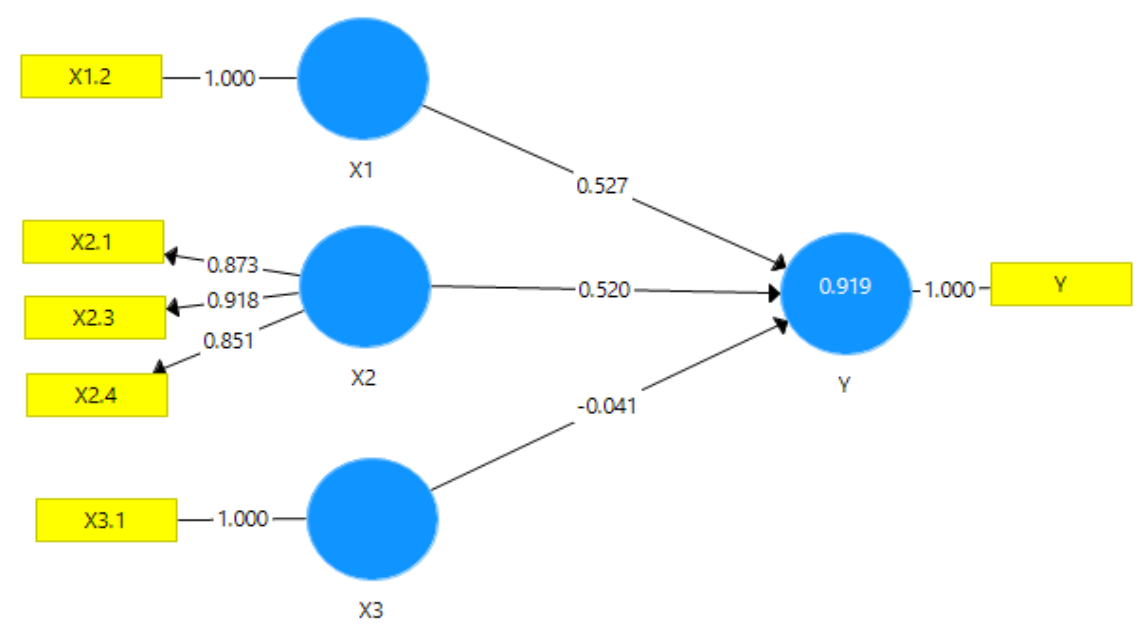

Sumber : data diolah, 2020

Tabel 5. Hasil Uji Reliabilitas

\begin{tabular}{cccc}
\hline Konstruk & Cronbach's Alpha & Composite Reliability & Keterangan \\
\hline X1 & 1,000 & 1,000 & reliabel \\
X2 & 0,856 & 0,912 & reliabel \\
X3 & 1,000 & 1,000 & reliabel \\
Y & 1,000 & 1,000 & reliabel \\
\hline
\end{tabular}

Sumber: data diolah, 2020

Hasil uji reliabilitas pada tabel 5 dapat diketahui dari perhitungan program smart PLS pada nilai composite reliability dan nilai cronbach's alpha. Variabel dikatakan reliabel ketika nilai dari hasil composite reliability dan nilai cronbach's alpha untuk seluruh konstruk adalah lebih besar dari 0,7. Dengan demikian variabel X1, X2, X3, dan Y dapat dikatakan reliabel karena nilainya lebih besar dari 0,7 .

Evaluasi model yang kedua adalah evaluasi model struktural (inner model) dengan melihat uji R-squared $\left(\mathrm{R}^{2}\right)$ dan predictive relevance $\left(\mathrm{Q}^{2}\right)$. Nilai R-squared $\left(\mathrm{R}^{2}\right)$ dari analisis PLS adalah 0,91 yang artinya pengaruh inklusi keuangan yang digambarakan oleh Availability, Access, dan Usage berpengaruh sebesar $91 \%$ terhadap pertumbuhan ekonomi dan sisanya 9\% dijelaskan oleh variabel-variabel lain yang belum masuk dalam model. Sedangkan nilai dari predictive relevance $\left(\mathrm{Q}^{2}\right)$ sebesar 0,873 dimana lebih besar dari 0 . Ini menunjukkan bahwa penerapan inklusi keuangan yang diwakili oleh variabel 
Availability, Access, dan Usage memiliki tingkat prediksi yang baik terhadap pertumbuhan ekonomi di Indonesia.

Tabel 6. Hasil Perhitungan Bootstrapping (Uji Signifikansi)

\begin{tabular}{|c|c|c|c|c|c|}
\hline & $\begin{array}{c}\text { Original } \\
\text { Sample } \\
\text { Estimate }(\mathrm{O}) \\
\text { (Path } \\
\text { Coefficients) }\end{array}$ & $\begin{array}{l}\text { Sample } \\
\text { Mean } \\
\text { (M) }\end{array}$ & $\begin{array}{l}\text { Standard } \\
\text { Deviation } \\
\text { (STD) }\end{array}$ & $\begin{array}{c}\text { T-Statistics } \\
\text { (IO/STDE } \\
\text { VI) }\end{array}$ & P-Values \\
\hline $\begin{array}{c}\text { Availability }(\mathrm{X} 1) \rightarrow \\
\text { Pertumbuhan } \\
\text { Ekonomi (Y) }\end{array}$ & 0,527 & 0,495 & 0,109 & 4,843 & 0,000 \\
\hline $\begin{array}{l}\text { Access }(\mathrm{X} 2) \rightarrow \\
\text { Pertumbuhan } \\
\text { Ekonomi }(\mathrm{Y})\end{array}$ & 0,520 & 0,539 & 0,094 & 5,518 & 0,000 \\
\hline $\begin{array}{l}\text { Usage }(\mathrm{X} 3) \rightarrow \\
\text { Pertumbuhan } \\
\text { Ekonomi (Y) }\end{array}$ & $-0,041$ & 0,033 & 0,091 & 0,449 & 0,654 \\
\hline
\end{tabular}

Tabel 6 menunjukkan hasil path coefficient dan uji signifikansi bahwa variabel Availability (X1) dan Access (X2) memiliki nilai p-values sebesar 0,000 $<0,005$. Nilai original sample estimate sebesar 0,527 untuk variabel Availability (X1) dan 0,520 untuk variabel Access (X2) yang menunjukan arah hubungan variabel Availability (X1) dan Access (X2) terhadap variabel Pertumbuhan Ekonomi (Y) adalah positif. Ini artinya variabel laten Availability (X1) dan Access (X2) dengan indikatornya berpengaruh secara signifikan terhadap variabel laten Pertumbuhan Ekonomi (Y) dengan indikator-indikatornya. Sedangkan untuk variabel Usage (X3) memiliki nilai p-values sebesar 0,654 > 0,005 . Nilai original sample estimate menunjukan nilai negatif sebesar $-0,041$ yang menunjukan arah hubungan variabel Usage (X3) terhadap variabel Pertumbuhan Ekonomi (Y) adalah negatif. Ini artinya dalam variabel laten Usage (X3) dengan indikatornya tidak berpengaruh secara signifikan terhadap variabel laten Pertumbuhan Ekonomi (Y) dengan indikator-indikatornya. Selanjutnya untuk mengetahui model fit dapat dilihat dari nilai NFI pada analisa PLS, yaitu sebesar 0,884. Hal tersebut menunjukkan bahwa model yang diteliti $88,4 \%$ telah fit.

Hasil analisis data dengan PLS menunjukkan bahwa dari tiga variabel yang merupakan indeks iklusi keuangan, hanya dua variabel yang memiliki pengaruh secara signifikan terhadap pertumbuhan ekonomi di Indonesia, yaitu variabel Availability dan Access. Variabel yang tidak signifikan terhadap pengentasan kemiskinan adalah Usage. Indikator Availability yang berpengaruh signifikan dapat mendorong pertumbuhan ekonomi adalah jumlah mesin ATM karena ketersediaan layanan perbankan melalui ATM yang semakin meningkat dan tersebar di berbagai wilayah memberikan 
kemudahan masyarakat untuk bertransaksi kapanpun tanpa terbatas oleh waktu operasional kantor bank. Selain itu dengan menggunakan ATM dapat menghemat waktu sehingga transaksi keuangan lebih efektif dan efisien sehingga dapat mempercepat perputaran uang yang berdampak terhadap peningkatan pertumbuhan ekonomi melalui kenaikan Produk Domestik Bruto (PDB). Hasil ini sejalan dengan penelitian oleh (Kamboj, 2014); (Sharma, 2016); (Anwar \& Amri, 2017).

Indikator variabel Access yang yang berpengaruh signifikan dapat mendorong pertumbuhan ekonomi adalah kartu debit, kepemilikan rekening di bank, dan kartu e-money. Semakin banyak jumlah kartu debit yang beredar dan kepemilikan rekening di bank oleh masyarakat menandakan semakin meningkatnya akses masyarakat terhadap perbankan atau lembaga keuangan formal. Hal tersebut dapat memudahkan dan meningkatkan transaksi keuangan, seperti pemindahan uang dari satu pihak ke pihak lainnya, pembayaran berbagai jenis tagihan, dan kegiatan perdagangan yang dapat meningkatkan pertumbuhan ekonomi.

Masyarakat yang memiliki rekening di bank sekaligus kartu debit akan memiliki akses untuk menabung dan mendapat pinjaman atau kredit dari bank. Peningkatan tabungan dapat digunakan untuk investasi sehingga mendorong pertumbuhan ekonomi. Sedangkan untuk penyaluran kredit yang meningkat oleh bank dapat membantu meningkatkan pendapatan karena pinjaman dapat menjadi modal untuk masyarakat utamanya pinjaman yang digunakan untuk kegiatan produktif, sehingga output dalam perekonomian meningkat yang berdampak pada stimulasi pertumbuhan ekonomi. Peningkatan akses pada layanan keuangan berpengaruh positif terhadap pertumbuhan ekonomi selaras dengan penelitian dari (Onaolapo, 2015); (Sharma, 2016); (Anwar \& Amri, 2017); (Sethi \& Acharya, 2018).

Kartu e-money adalah uang elektronik yang digunakan sebagai alat pembayaran pengganti uang tunai. Perbankan menciptakan uang elektronik karena ingin mengurangi penggunaan uang tunai menuju era cashless society. Banyak manfaat yang dapat dirasakan masyarakat, seperti pembayaran lebih mudah dan cepat karena dapat menghemat waktu dan tidak perlu membawa uang tunai banyak kemana-mana karena lebih beresiko. Penguunaan e-money mudah diaplikasikan untuk segala jenis transaksi yang menyediakan pembayaran non tunai dan menciptakan pembayaran yang akurat, sehingga tidak ada pihak yang dirugikan. Oleh karena itu, peningkatan akses pada layanan keuangan melalui kepemilikan kartu e-money berimplikasi terhadap pertumbuhan ekonomi karena terjadi peningkatan pada transaksi dan perputaran uang yang menandakan aktivitas ekonomi juga meningkat.

\section{KESIMPULAN}

Hasil penelitian menunjukkan bahwa dari tiga variabel laten (indeks inklusi keuangan), hanya dua yang berpengaruh secara signifikan mendorong pertumbuhan ekonomi di Indonesia, yaitu Availability dan Access. Variabel Usage dengan indikator-indikatornya tidak memiliki pengaruh yang signifikan terhadap pertumbuhan ekonomi di Indonesia. Dua indikator dari 
variabel Availability (X1) hanya 1 indikator yang dapat mendorong pertumbuhan ekonomi Indonesia, yaitu ketersediaan mesin ATM. Pada variabel Access (X2) terdapat tiga dari empat indikator yang dapat mendorong pertumbuhan ekonomi Indonesia antara lain akses pada kartu debit, kepemilikan rekening di bank, dan kartu e-money.

Berdasarkan hasil penelitian, maka rekomendasi yang dapat diberikan untuk mendorong peningkatan pertumbuhan ekonomi di Indonesia melalui sektor keuangan adalah dengan inklusi keuangan khusunya pada availability atau ketersediaan lembaga keuangan yang dicerminkan dari jumlah mesin ATM di seluruh wilayah Indonesia untuk memudahkan masyarakat melakukan transaksi keuangan kapanpun tanpa harus datang ke kantor bank. Selain availability, access atau akses masyarakat terhadap layanan keuangan melalui kepemilikan rekening di bank, kartu debit dan kartu e-money terus ditingkatkan oleh lembaga keuangan melalui edukasi terhadap masyarakat, promosi yang gencar, dan kemudahan untuk memperolehnya. Semakin mudah akses, maka membuat transaksi keuangan meningkat sehingga menstimulus peningkatan pertumbuhan ekonomi.

\section{DAFTAR PUSTAKA}

Anwar, K., \& Amri, A. (2017). Pengaruh Inklusi Keuangan Terhadap PDB Indonesia. Jurnal Ilmiah Mahasiswa Ekonomi Pembangunan Fakultas Ekonomi Dan Bisnis Unsyiah, 2(3), 454-462.

Bank Indonesia. (2014). Booklet Keuangan Inklusif. Departemen Pengembangan Akses Keuangan dan UMKM Bank Indonesia.

Bank Indonesia. (2020). Keuangan Inklusif. Bank Indonesia. https://www.bi.go.id/id/fungsi-utama/stabilitas-sistem-

keuangan/keuangan-inklusif/Default.aspx

Cámara, N., \& Tuesta, D. (2017). Measuring financial inclusion: a multidimensional index 1 Measuring financial inclusion: a multidimensional index. Bank for International Settlements, September. https://www.bis.org/ifc/publ/ifcb47p.pdf

Cheng, X., \& Degryse, H. (2010). The Impact of Bank and Non-Bank Financial Institutions on Local Economic Growth in China. Journal of Financial Services Research, 37(2-3), 179-199. https://doi.org/10.1007/s10693-009-0077-4

Dienillah, A. A., \& Anggraeni, L. (2016). Dampak Inklusi Keuangan Terhadap Stabilitas Sistem Keuangan Di Asia. Buletin Ekonomi Moneter Dan Perbankan, 18(4), 409-430. https://doi.org/10.21098/bemp.v18i4.574

Dupas, Pascaline, Green, Sarah, Keats, Anthony, Robinson, J. (2012). Challenges in Banking the Rural Poor: Evidence From Kenya's Western Province. NBER Working Paper, 17851, 1-41. https://doi.org/10.7208/chicago/9780226315867.003.0004 
Hanivan, H., \& Nasrudin, N. (2019). A financial inclusion index for Indonesia. Buletin Ekonomi Moneter Dan Perbankan, 22(3), 351-366. https://doi.org/10.21098/bemp.v22i3.1056

Hannig, A., \& Jansen, S. (2011). Financial inclusion and financial stability: Current policy issues. In Financial Market Regulation and Reforms in Emerging Markets (Issue 259). https://doi.org/10.2139/ssrn.1729122

Kamboj, S. (2014). Financial Inclusion and Growth of Indian Economy : An Empirical Analysis. The International Journal of Business and Management, 2(9), 175-179.

Khan, S. H. R. (2011). Financial inclusion and financial stability: are they two sides of the same coin? Indian Bankers Association \& Indian Overseas Bank, Chennai, November, 1-12. https://www.bis.org/review/r111229f.pdf

Kim, D. W., Yu, J. S., \& Hassan, M. K. (2018). Financial inclusion and economic growth in OIC countries. Research in International Business and Finance, 43, 1-14. https://doi.org/10.1016/j.ribaf.2017.07.178

Mwaitete, C. P., \& George, L. A. (2018). Finaancial inclusion and economic growth a regression analysis. Imperial Journal of Interdisciplinary Research (IJIR), 4(1), 265-288.

Onaolapo, A. R. (2015). Effects of financial inclusion on the economic growth of Nigeria (1982-2012). International Journal of Business and Management Review, 3(8), 11-28.

Ouma, S. A., Odongo, T. M., \& Were, M. (2017). Mobile financial services and financial inclusion: Is it a boon for savings mobilization? Review of Development Finance, $\quad 7(1), \quad 29-35$. https://doi.org/10.1016/j.rdf.2017.01.001

Sanjaya, I Made, N. (2016). Inklusi Keuangan dan Pertumbuhan Inklusif: Analisis Antar Provisni di Indonesia. Buletin Ekonomi Moneter Dan Perbankan, 18(3), 281-306. http://lib.ibs.ac.id/materi/BI Corner/Terbitan BI/Jurnal Ekonomi/BEMP Tahun 2016/1. BEMP Vol 18 No 3 Januari 2016.pdf\#page $=55$

Sarma, M. (2008). Index of Financial Inclusion. 215. https://doi.org/10.1007/978-81-322-1650-6_28

Sarma, M., \& Pais, J. (2008). Financial Inclusion and Development: A Cross Country Analysis. In Annual Conference of the Human Development and Capability Association, New Delhi, 168(10-13), 1-30. https://doi.org/10.1002/jid

Sethi, D., \& Acharya, D. (2018). Financial inclusion and economic growth linkage: some cross country evidence. Journal of Financial Economic Policy, 10(3), 369-385. https://doi.org/10.1108/JFEP-11-2016-0073

Sharma, D. (2016). Nexus between financial inclusion and economic growth: 
Evidence from the emerging Indian economy. Journal of Financial Economic Policy, 8(1), 13-36. https://doi.org/10.1108/JFEP-01-2015-0004

Swamy, V. (2014). Financial Inclusion, Gender Dimension, and Economic Impact on Poor Households. World Development, 56, 1-15. https://doi.org/10.1016/j.worlddev.2013.10.019

Uddin, G. S., Shahbaz, M., Arouri, M., \& Teulon, F. (2014). Financial development and poverty reduction nexus: A cointegration and causality analysis in Bangladesh. Economic Modelling, 36, 405-412. https://doi.org/10.1016/j.econmod.2013.09.049

Ummah, B. B., Nuryartono, N., \& Anggraeni, L. (2018). Analisis Inklusi Keuangan Dan Pemerataan Pendapatan Di Indonesia. Jurnal Ekonomi Dan Kebijakan Pembangunan, 4(1), 1-27. https://doi.org/10.29244/jekp.4.1.1-27

Zins, A., \& Weill, L. (2016). The determinants of financial inclusion in Africa. Review of Development Finance, 6(1), 46-57.

https://doi.org/10.1016/j.rdf.2016.05.001 